\title{
Clinical and histological comparison of the soft tissue morphology between zirconia and titanium dental implants under healthy and experimental mucositis conditions - A randomized controlled clinical trial
}

Bienz, Stefan P ; Hilbe, Monika ; Hüsler, Jürg ; Thoma, Daniel S ; Hämmerle, Christoph H F ; Jung, Ronald E

DOI: https://doi.org/10.1111/jcpe.13411

Posted at the Zurich Open Repository and Archive, University of Zurich ZORA URL: https://doi.org/10.5167/uzh-193250

Journal Article

Accepted Version

Originally published at:

Bienz, Stefan P; Hilbe, Monika; Hüsler, Jürg; Thoma, Daniel S; Hämmerle, Christoph H F; Jung, Ronald $\mathrm{E}$ (2021). Clinical and histological comparison of the soft tissue morphology between zirconia and titanium dental implants under healthy and experimental mucositis conditions - A randomized controlled clinical trial. Journal of Clinical Periodontology, 48(5):721-733.

DOI: https://doi.org/10.1111/jcpe.13411 
DR. STEFAN PATRICK BIENZ (Orcid ID : 0000-0002-8562-1580)

PROF. DANIEL STEFAN THOMA (Orcid ID : 0000-0002-1764-7447)

DR. RONALD E JUNG (Orcid ID : 0000-0003-2055-1320)

Article type : Original Article Implant Dentistry

Clinical and histological comparison of the soft tissue morphology between zirconia and titanium dental implants under healthy and experimental mucositis conditions

\section{- A randomized controlled clinical trial}

Stefan P. Bienz, Dr. med. dent. ${ }^{1}$, Monika Hilbe, Dr. med. vet. ${ }^{2}$, Jürg Hüsler, Prof. Dr. ${ }^{1}$, Daniel

S. Thoma, Prof. Dr. med. dent. ${ }^{1,3}$, Christoph H. F. Hämmerle, Prof. Dr. med. dent. ${ }^{1}$, Ronald E. Jung, Prof. Dr. med. dent. ${ }^{1}$

Key words: Peri-implant soft tissue, mucositis, zirconia implant, histology,

histomorphometry

Running title: ZrO2vsTi

Number of Figures: 4

Number of Tables: 3

Address for correspondence:

Prof. Dr. med. dent. Ronald E. Jung

Clinic of Reconstructive Dentistry

Center of Dental Medicine, University of Zurich

Plattenstrasse 11

$\mathrm{CH}-8032$ Zurich, Switzerland

Phone: +41446340404

This article has been accepted for publication and undergone full peer review but has not been through the copyediting, typesetting, pagination and proofreading process, which may lead to differences between this version and the Version of Record. Please cite this article as doi: 10.1111/JCPE.13411

This article is protected by copyright. All rights reserved 
Fax: +41446344305

e-mail: ronald.jung@zzm.uzh.ch

${ }^{1}$ Clinic of Reconstructive Dentistry, University of Zurich, Zurich, Switzerland

${ }^{2}$ Institute of Veterinary Pathology, Vetsuisse Faculty, Zurich, Switzerland

3 Department of Periodontology, Research Institute for Periodontal Regeneration, College of Dentistry, Yonsei University, Seoul, Korea

This article is protected by copyright. All rights reserved 


\section{Author contributions:}

R.J. conceived the idea; R.J. / S.B. prepared the protocol; D.T. / S.B. / R.J. performed the treatments; S.B. retrieved the biopsies; M.H. performed the descriptive histologic assessment; S.B. collected the data; J.H. / S.B. / R.J. / D.T. analyzed the data; S.B. / R.J. led the writing and all authors reviewed the manuscript.

This article is protected by copyright. All rights reserved 


\section{Abstract}

Objectives: To analyze the soft tissue morphology under healthy and experimental mucositis conditions comparing zirconia and titanium implants.

Methods: Forty-two patients with two adjacent missing teeth received one zirconia ( $\mathrm{Zr}$ ) and one titanium ( $\mathrm{Ti}$ ) implant, with the mesial and distal position randomized. At 3 months, half of the patients were instructed to continue (healthy; $h$ ) and the other half to omit (experimental mucositis; $\mathrm{m}$ ) oral hygiene around the implants for 3 weeks. Clinical parameters were evaluated before and after the experimental phase and a soft tissue biopsy was harvested. Mixed model analyses were performed to analyze the data.

Results: The plaque control record increased significantly for the two mucositis groups, reaching $68.3 \pm 31.9 \%$ (mean \pm standard deviation) for $\mathrm{Zr}-\mathrm{m}$ and $75.0 \pm 29.4 \%$ for Ti-m $(p<0.0001)$, being also significantly lower for $\mathrm{Zr}-\mathrm{m}$ than for Ti-m. Bleeding on probing remained stable in group $\mathrm{Zr}-\mathrm{m}$ and amounted to $21.7 \pm 23.6 \%$, but increased significantly in group Ti-m $(p=0.040)$, measuring $32.5 \pm 27.8 \%$. The number of inflammatory cells and the length of the junctional epithelium did not significantly differ between the groups.

\section{Conclusion:}

Both implants rendered similar outcomes under healthy conditions. Lower plaque and bleeding scores were detected for zirconia implants under experimental mucositis conditions. Histologically, only minimal differences were observed.

This article is protected by copyright. All rights reserved 


\section{Clinical Relevance}

Scientific rationale for the study: Zirconia dental implants have drawn attention as a metalfree solution in implant dentistry during the last decade. Zirconium dioxide is claimed to be a material with favorable properties in terms of soft tissue integration. Currently, clinical data on a histological level is scarce and settings comparing the material directly with titanium implants are lacking.

Principal findings: Zirconia implants rendered similar outcomes under healthy conditions, but lower plaque and bleeding scores were detected under experimental mucositis conditions. Histologically, only minimal differences were observed between zirconia and titanium implants.

Practical implications: With focus on soft tissue integration, slightly more favorable clinical results were found for zirconia implants. 


\section{Introduction}

Dental implants offer a predictable treatment modality for replacing single or multiple missing teeth with the ultimate goal to restore function, comfort and esthetics of the patient (Jung, Zembic, Pjetursson, Zwahlen, \& Thoma, 2012; Pjetursson, Thoma, Jung, Zwahlen, \& Zembic, 2012). Titanium and titanium alloys are considered the gold standard due to favorable physico-chemical properties, their biological attributes allowing for osseointegration and the long-term documentation in oral implantology (Branemark et al., 1977; Schroeder, Pohler, \& Sutter, 1976).

Despite the overall promising outcomes, some implants display bone loss or even fail after successful initial osseointegration (De Bruyn et al., 2017). Plaque-induced inflammation is proven to have a cause-effect relationship on bone loss and might be considered the most important or at least most thoroughly studied factor (Lindhe, Berglundh, Ericsson, Liljenberg, \& Marinello, 1992). More recently, further mechanisms have been studied, mainly considering immune-osteolytic responses inducing bone loss (Albrektsson, Canullo, Cochran, \& De Bruyn, 2016). The presence of free titanium particles around implants was proven in preclinical models (Guglielmotti et al., 2015; Schliephake, Reiss, Urban, Neukam, \& Guckel, 1993) and is together with biocorrosion of titanium (Barão et al., 2012) a potential trigger, by leading to free ions and thereby inducing the interleukin-1ß pathway (Pettersson et al., 2017). However, there is currently insufficient evidence to state a clear cause-effect relationship in clinical scenarios (Mombelli, Hashim, \& Cionca, 2018).

Zirconium dioxide has the potential to overcome these issues due to its different material properties. Various preclinical and clinical trials demonstrated zirconia dental implants to fulfill the basic principles for successful osseointegration (Balmer et al., 2020; Balmer et al., 2018; Depprich et al., 2008; Kohal, Weng, Bachle, \& Strub, 2004; Oliva, Oliva, \& Oliva, 2007). In addition, several preclinical and clinical reports indicate advantages of zirconium dioxide on the soft tissue level: i) Limited evidence is available demonstrating that zirconia exhibits lower bacterial colonization potential compared to titanium (Roehling et al., 2017; Scarano, Piattelli, Caputi, Favero, \& Piattelli, 2004). ii) Favorable soft tissue responses were reported for zirconia abutments in preclinical studies in terms of soft tissue thickness, length of the junctional epithelium and marginal bone loss (Abrahamsson, Berglundh, Glantz, \& Lindhe, 1998; Welander, Abrahamsson, \& Berglundh, 2008). iii) A recent canine model revealed significantly less bone loss in a ligature-induced plaque accumulation model for zirconia compared to titanium implants (Roehling et al., 2019). iv) Improved epithelial attachment around zirconia implants compared to titanium implants in 6 minipigs (Linares et

This article is protected by copyright. All rights reserved 
al., 2016).

The present clinical evidence for zirconia implants is limited to prospective trials in noncontrolled settings (Roehling, Schlegel, Woelfler, \& Gahlert, 2018).

Therefore, the aim of the present study was to clinically and histologically evaluate the soft tissue morphology under healthy and experimental mucositis conditions comparing zirconia and titanium dental implants in a randomized, controlled study design.

This article is protected by copyright. All rights reserved 


\section{Material and Methods}

This study was designed as a prospective, randomized controlled clinical trial with two consecutive randomization processes resulting in four equal treatment groups. A total of 40 patients were recruited for the present study. All patients gave written informed consent and research was performed according to the Helsinki protocol. The present study was approved by the local ethical committee KEK-ZH-Nr. 2015-0215 (PB_2016-01767) and is registered in the German Register of Clinical Trials (DRKS00008591).

\section{Study population}

Patients presenting at the Clinic of Reconstructive Dentistry were consecutively enrolled between June 2015 and February 2019. Prerequisite were two missing adjacent teeth in the maxilla or mandible in positions of premolars and molars with at least one tooth present adjacent to the edentulous space and the need/wish for a reconstruction on dental implants.

Inclusion criteria:

- Male and female patients 18 years to 80 years of age

- No general medical condition which represents a contraindication to implant treatment

- At least $10 \mathrm{~mm}$ of vertical bone height in the mandible allowing for placement of an $8 \mathrm{~mm}$ implant ( $2 \mathrm{~mm}$ safety distance to inferior alveolar nerve)

- At least $6 \mathrm{~mm}$ of vertical bone height in the maxilla allowing for placement of an $8 \mathrm{~mm}$ implant (in combination with a simultaneous, transcrestal augmentation)

- At least $2 \mathrm{~mm}$ of keratinized tissue

\section{Exclusion criteria:}

- Smoking of more than 15 cigarettes a day

- Poor oral hygiene after hygienic phase (Plaque control record over 30\%)

- Active periodontal disease

- Women who were pregnant or breast feeding at the date of inclusion

\section{Implant placement}

Following the screening visit, patients were scheduled for implant placement. Before surgery, patients rinsed for 60 seconds with a solution containing $0.2 \%$ chlorhexidine (Kantonsapotheke Zürich, Zürich, Switzerland) and received $500 \mathrm{mg}$ of an analgesic (Mefenacid, Streuli Pharma, Uznach, Switzerland). The site was then carefully anesthetized 
(Ultracain ${ }^{\circledR}$ D-S, Hoechst-Pharma AG, Zurich, Switzerland) and a mucoperiosteal flap was raised. The flap design consisted of sulcular incisions at the neighboring teeth and a crestal incision, which divided the keratinized tissue equally in the mandible, or connected the palatal line angles in the maxilla (Figure 1a). The implant bed was prepared according to the manufacturer's instructions. After preparation with a $\varnothing 3.5 \mathrm{~mm}$ drill, a sealed envelope was opened containing the allocation of the implants according to a computer-generated list ( $\mathrm{n}=$ 20 per group, https://www.random.org/):

- Zirconia implant (ZrO2): PURE Ceramic Implant Monotype $\varnothing 4.1 \mathrm{~mm}, \mathrm{ZLA}^{\mathrm{TM}}$ (Institut Straumann AG, Basel, Switzerland) made from yttrium-stabilized zirconium dioxide.

- Titanium implant (Ti): Standard Plus Implant $\varnothing 4,1 \mathrm{~mm}$, Regular Neck $\varnothing$ 4,8mm, $S L A \circledast$, (Institut Straumann AG) made from commercially pure titanium.

Both implants featured a similar shape and a polished surface of their soft tissue component with $1.8 \mathrm{~mm}$ of height. Selective profile drilling and thread tapping was performed according to the implant allocation, the local bone density and the shape of the surrounding crestal bone. Subsequently, implants were placed with a maximum torque of 35NCM for zirconia and 50 NCM for titanium implants (Figure 1b). For the zirconia implants, the abutment height ( $4 \mathrm{~mm}$ or $5.5 \mathrm{~mm}$ ) was selected depending on the occlusal clearance.

In case of thin buccal bone plates $(<1.5 \mathrm{~mm})$, dehiscence or fenestration defects, a guided bone regeneration procedure (GBR) was performed. Deproteinized bovine bone mineral (DBBM; Bio-Oss ${ }^{\circledR}$, Geistlich Pharma AG) granules and/or DBBM with $10 \%$ Collagen (Bio-Oss ${ }^{\circledR}$ Collagen, Geistlich Pharma AG) was used in combination with a native collagen membrane (Bio-Gide ${ }^{\circledR}$, Geistlich Pharma AG), optionally fixed with resorbable pins (LeadFIX, ImperiOs, Bad Homburg, Germany). In case of transcrestal sinus elevation, DBBM with $10 \%$ collagen (Bio-Oss ${ }^{\circledR}$ Collagen, Geistlich Pharma AG) was used. All implants healed transmucosally. Horizontal mattress sutures and single interrupted sutures (Gore-tex ${ }^{\circledR}$ 5/0, W.L. Gore \& Associates, Flagstaff, AZ, USA) adapted the tissues and secured the position of the flap (Figure 1c).

Postoperatively, patients rinsed with a solution containing $0.2 \%$ chlorhexidine (Kantonsapotheke Zürich) twice per day for seven days. Analgesics (Mefenacid, Streuli Pharma) were provided and used according the patient's individual needs. In case of application of a biomaterial, patients received $750 \mathrm{mg}$ of amoxicilline (Amoxicillin Sandoz, Sandoz, Basel, Switzerland) three times per day for 5 days. Inspection of the surgical site and suture removal was performed after 7-10 days. Thereafter, patients were instructed to start cleaning the site gently with a soft toothbrush for another three weeks, before regular hygiene could be continued. 


\section{Experimental mucositis}

Three months after implant placement, patients returned for all baseline ( $B L$ ) measurements and the second randomization cycle. A microbiological sample was retrieved at the mesial or distal aspect of the implant (always facing the other implant) with a sterile paper point, after removing supragingival plaque. Plaque control record (PCR), probing depth (PD) and bleeding on probing (BoP) was recorded at six sites of each implant. Keratinized tissue (KT) was recorded buccally of each implant.

Thereafter, an experimental mucositis phase followed for a duration of three weeks. The experiment was conducted as first described around teeth (Loe, Theilade, \& Jensen, 1965), but also around implants in later studies (Chan, Pelekos, Ho, Cortellini, \& Tonetti, 2019; Salvi et al., 2012). In case of an allocation to the healthy (h) group, patients were advised to continue cleaning and avoiding any alterations of their habits. In case of an allocation to the mucositis $(m)$ group, patients were instructed to omit cleaning the site and the neighboring teeth and to avoid mouthrinses. The second randomization divided all sites into 4 equal groups: zirconia, healthy (Zr-h); titanium, healthy (Ti-h); zirconia, mucositis (Zr-m); titanium, mucositis (Ti-m).

At three weeks ( $3 W$ ), the measurements were repeated, prior to the harvesting a soft tissue biopsy. Healing abutments on titanium implants were removed and the sulcular area was cleaned gently with a foam pellet (Pele Tim, Voco GmbH, Cuxhaven, Germany) soaked with $0.2 \%$ chlorhexidine (Kantonsapotheke Zürich). Scalers were used carefully whenever it was necessary to remove hard debris. Following local anesthesia (Ultracain ${ }^{\circledR}$ D-S, HoechstPharma AG), two parallel, crestal, full-thickness incisions connecting the buccal and oral line angles were performed (Figure $2 \mathrm{a}$ ). The buccal and oral tissues were slightly mobilized before the buccal side of the biopsy was marked with a single interrupted suture (Premilene No. 7/0, B.Braun Melsungen AG) (Figure $2 b+c$ ). In order to prepare the prosthetic treatment, a PEEK cap was snapped onto the zirconia implant, and slight soft tissue adaptations were made if necessary. A suitable healing abutment was inserted onto the titanium implant and the soft tissues were adapted with an inverting, external mattress suture (Gore-tex ${ }^{\circledR} 5 / 0$, W.L. Gore \& Associates) (Figure $2 \mathrm{~d}$ ). Patients were advised to rinse with a solution containing $0.2 \%$ chlorhexidine (Kantonsapotheke Zürich) twice per day for seven days. Moreover, a dental adhesive paste was provided and the application was instructed to the patient (Solcoseryl, MEDA Pharmaceuticals, Wangen, Switzerland). Sutures were removed 7-10 days later and wound healing as well as the resolution of the experimental mucositis was examined.

\section{Microbiological testing}


A multiplex real-time polymerase chain reaction test was performed (IAI Pado Test, Institut IAI, Zuchwil, Switzerland). Bacterial ribosomal 16S rRNA was detected and allowed quantification of total bacterial load and presence of six periodontal marker pathogens (Aggregatibacter actinomycetemcomitans, Porphyromonas gingivalis, Tannerella forsythia, Treponema denticola, Prevotella intermedia, Filifactor alocis).

\section{Histologic processing}

After at least 48 hours in formalin, the specimens were dehydrated and infiltrated with xylol and paraffin (Paraffin at $60^{\circ}$ Celsius). Before embedding the biopsy, the orientation suture was removed. A central section was cut into 2-5 $\mu \mathrm{m}$ thick sections with a microtome (MICROM, Medite $\mathrm{GmbH}$, Dietlikon, Switzerland). Two sections of each biopsy were retrieved, one was stained with Hematoxylin-eosin and one with Elastica - Van Gieson.

\section{Histologic assessment}

A blinded pathologist performed a descriptive assessment using an optical microscope (Olympus CX41, Olympus Corporation, Tokyo, Japan). For each parameter, a scoring system ranging between 0 and 3 was applied. Parameters encompassed the number of neutrophil granulocytes, eosinophil granulocytes, lymphocytes, plasma cells and macrophages within the epithelium. In the lamina propria, neutrophil granulocytes, eosinophil granulocytes, lymphocytes, plasma cells, macrophages and collagen density were evaluated.

\section{Histomorphometric analysis}

The analysis was performed by a blinded histologist using an optical microscope (Leica CTR600, Leica, Wetzlar, Germany) at 200x magnification. The length of the junctional epithelium was measured by following the surface of the epithelium (LAS V4.3, Leica). The overall soft tissue thickness was measured vertically (Figure $3 a$ ). Furthermore, the ratio of the two measurements was calculated and expressed as a percentage.

Four regions of interest, standardized in size, were placed along the peri-implant soft tissue interface of the titanium and zirconia implant (Figure 3a). The regions of interest were placed behind the epithelium at the following levels: oral epithelium, sulcular epithelium, junctional epithelium, supracrestal connective tissue (Thoma et al., 2018). An image editing software (Adobe Photoshop CS6 extended, Adobe Systems, San José, CA, USA) was used to mark inflammatory cells, fibroblasts, epithelium and background. The percentage of the area of all subgroups was then calculated for a semi-quantitative analysis (LAS V4.3, Leica).

This article is protected by copyright. All rights reserved 
Data was computed in Excel (Microsoft Corp., Redmond, WA, USA) and statistical analysis was performed with SAS 9.4 (SAS Corp., Cary NC. USA). Means and standard deviations as well as medians with quartiles were used to describe continuous variables, counts and percentages were used for categorical variables. The number of inflammatory cells at the level of the junctional epithelium was determined as the primary outcome and used as one of the dependent variables in the models (Berglundh et al., 1991). Parametric and mostly nonparametric linear mixed models (MM) (Brunner et al., 2001) were applied, depending on the satisfied model assumptions. The normality assumption was not holding for most of the parameters. The independent variables in all models were the group variables with the four groups $\mathrm{Zr}-\mathrm{h}$, Ti-h and Zr-m, Ti-m, sometimes also with time as a variable together with their interaction. The random effect was the patient because of the clustered data within a patient. Logistic mixed models were applied in order to analyze counts and percentages. In addition, to analyze possible confounding effects, more complex models consisted of the independent factors implant, cleaning and an additional variable of interest. Simple parametric or nonparametric linear models were based on the differences $\mathrm{Ti}$ - Zr within each patient. The level of significance was set at $5 \%$ and no correction for multiple testing for the several parameters was applied. For the pairwise comparisons of $\mathrm{Ti}$ - $\mathrm{Zr}$ under healthy and under mucositis conditions, 95\%-confidence intervals were derived by parametric or nonparametric methods corresponding to the applied mixed model, applying also the Bonferroni correction for the comparisons per selected parameter.

This article is protected by copyright. All rights reserved 


\section{Results}

A total of 42 patients were screened and participated in the study. They received 84 implants, which all healed successfully. One patient could not be further treated after implant placement due to aggravated general medical conditions. Another biopsy was excluded from the analysis due to insufficient quality. Forty biopsies were successfully analyzed. Baseline characteristics of these patients are summarized in Table 1. Median age amounted to 52.5 years (first quartile $(\mathrm{Q} 1)=36.8$; third quartile $(\mathrm{Q} 3)=61.3$ ) for groups $\mathrm{Zr}-\mathrm{h} / \mathrm{Ti}-\mathrm{h}$ and 62.1 years $(\mathrm{Q} 1=51.5 ; \mathrm{Q} 3=69.5)$ in groups $\mathrm{Zr}-\mathrm{m} / \mathrm{Ti}-\mathrm{m}$.

\section{Clinical parameters}

All descriptive results are reported in Table 2 and confidence intervals are given in Appendix 2. At baseline, the plaque control record (PCR) as a dependent variable was significantly lower in group $\mathrm{Zr}-\mathrm{m}$ with $4.2 \pm 7.4 \%$ (mean \pm standard deviation) as compared to the other three groups with values ranging from $10.8 \pm 21.1 \%$ and $14.2 \pm 27.2 \%$ (nonparam. MM: intergroup $p=0.003)$. At $3 \mathrm{~W}$, significantly different values were obtained for the mucositis groups (nonparam. MM: intergroup $\mathrm{p}<0.001$ ), amounting to $68.3 \pm 31.9 \%$ for $\mathrm{Zr}-\mathrm{m}$ and $75.0 \pm 29.4 \%$ for Ti-m, Ti-m also being significantly higher than Zr-m $(p=0.039)$. These changes were also significant in time for these two groups (intragroup: $p<0.001 ; p<0.001$ ). PCR is also presented in Figure 4a.

At baseline, bleeding on probing (BoP) as a dependent variable was significantly lower in group Ti-m with $15.8 \pm 18.3 \%$ as compared to the other groups, which were ranging from $20.8 \pm 18.6 \%$ to $22.5 \pm 23.7 \%$ (nonparam. MM: intergroup $p=0.0157$ ). The values decreased in the two healthy groups, since the measurements at $3 \mathrm{~W}$ amounted to $11.7 \pm 18.8 \%$ in $\mathrm{Zr}-\mathrm{h}$ and $11.7 \pm 16.3 \%$ in Ti-h (nonparam. MM: intragroup: $p=0.025 ; p=0.481$ and for the $3 \mathrm{~W}$ data: nonparam. $\mathrm{MM}$ : intergroup $\mathrm{p}=0.554)$. BoP remained stable in group $\mathrm{Zr}-\mathrm{m}$ with $21.7 \pm 23.6 \%$ (nonparam. $M M$ : intragroup $p=0.8390$ ), but increased significantly in group Ti$\mathrm{m}$ and amounted to $32.5 \pm 27.8 \%$ (nonparam. MM: intragroup: $\mathrm{p}=0.039$ ), resulting in a significant difference when comparing the experimental mucositis groups at $3 \mathrm{~W}$ (nonparam. MM: intergroup of the mucositis groups: $p<0.001$, and all 4 groups: $p<0.001$ ). BoP is also presented in Figure 4b.

Probing depth (PD) ranged between $2.6 \pm 0.5 \mathrm{~mm}$ and $2.7 \pm 0.7 \mathrm{~mm}$ in all $\mathrm{BL}$ measurements (param. MM: intergroup $p=0.772$ ). The values decreased slightly in all groups and measured between 2.4 $\pm 0.4 \mathrm{~mm}(\mathrm{Zr}-\mathrm{m})$ and $2.6 \pm 0.4 \mathrm{~mm}(\mathrm{Ti}-\mathrm{m})$ (param. MM: intergroup $\mathrm{p}=0.093$ ).

This article is protected by copyright. All rights reserved 


\section{Microbiology}

Total bacterial loads ranged from $15.3 \pm 15.0$ millions to $29.1 \pm 28.7$ millions in $B L$ and $3 W$ measurements (nonparam. MM intergroup: $p=0.176$ and $p=0.334$ ). The presence of $a$ marker pathogen ranged between 0 out of 18 ( $0 \%$; group Ti-m, BL) and 3 out of 15 (17\%; group Zr-m, BL). There were no significant differences between groups ( $p>0.05$, for both $B L$ and $3 \mathrm{~W}$, based on logistic mixed models). Descriptive data is summarized in Appendix 1.

\section{Descriptive Histology}

A matured oral epithelium with few keratinized layers and with deep rete pegs was observed in the center of the biopsies, transiting into a distinct junctional epithelium towards the implants. The number of neutrophil granulocytes, eosinophil granulocytes, lymphocytes, plasma cells and macrophages in the epithelium was very low, only scores 0 and 1 were observed. The length of the junctional epithelium appeared to vary heavily between patients, but did merely differ when comparing the two sides of a biopsy facing the two implant surfaces (Figure $3 b+c$ ).

The lamina propria mainly consisted of dense collagen fibers with scores ranging from $2.6 \pm 0.5$ to $2.7 \pm 0.4$ (Figure $3 a-c$ ). Only scores 0 and 1 were observed for neutrophil granulocytes, the frequency of score 1 ranged between 2 out of $20(10 \%$, Ti-h) and 4 out of $20(20 \%, Z r-h)$. Similar for the number of macrophages, maximum scores of 1 were found with a frequency of 10 out of 20 (50\%, Ti-h and Ti-m) and 11 out of 20 (55\%, Zr-h and Zr$\mathrm{m})$. No eosinophil granulocytes were found despite one site with a score of 1 (group Ti-h). Higher scores were obtained for lymphocytes and plasma cells (lowest Ti-m: 1.1 \pm 0.5 ; highest $\mathrm{Zr}-\mathrm{h}: 1.5 \pm 0.8$ and Ti-h $1.5 \pm 0.7)$. Nine sites in 8 patients were scored with a maximum of 3 and showed a distinct infiltrate behind the junctional epithelium, mainly consisting of lymphocytes and plasma cells. Only one patient (Randomized as healthy, PCR: $0 \%$ ) showed an obvious infiltrate at both implants. Seven out of these 9 infiltrates were seen at a zirconia implant and 6 out of 9 were found in the healthy groups.

\section{Histomorphometric analysis}

All descriptive results are reported in Table 3 and confidence intervals are given in Appendix 2. The primary outcome, the number of inflammatory cells at the level of the junctional epithelium, amounted to $4.8 \pm 5.7 \%$ in group $\mathrm{Zr}-\mathrm{h}, 3.1 \pm 5.7 \%$ for Ti-h, $2.0 \pm 3.2$ for $\mathrm{Zr}-\mathrm{m}$ and $2.2 \pm 3.1 \%$ for Ti-m (Figure $4 \mathrm{c}$ ). The differences between the groups were not significant (nonparam. MM: intergroup $\mathrm{p}=0.251$ ). 
Based on 22 evaluated biopsies, the length of the junctional epithelium amounted to $1213.5 \pm 243.3 \mu \mathrm{m}$ for $\mathrm{Zr}-\mathrm{h}, 1344.6 \pm 430.1 \mu \mathrm{m}$ for Ti-h, $1664.8 \pm 668.8 \mu \mathrm{m}$ for $\mathrm{Zr}-\mathrm{m}$ and $1557.6 \pm 473.3 \mu \mathrm{m}$ for Ti-m. The differences between the 4 groups were not significant (param. MM intergroup: $p=0.161$ ).

The overall tissue thickness amounted to $1924.9 \pm 476.3 \mu \mathrm{m}$ for $\mathrm{Zr}-\mathrm{h}, 2056.4 \pm 431.9 \mu \mathrm{m}$ for Ti$\mathrm{h}, 2484.8 \pm 431.3 \mu \mathrm{m}$ for $\mathrm{Zr}-\mathrm{m}$ and $2387.2 \pm 510.4 \mu \mathrm{m}$ for Ti-m (param. MM intergroup: $\mathrm{p}=0.029$ ). In particular using cleaning as explanatory variable, the comparison of the two cleaning groups showed a significant difference (param. MM cleaning: $p=0.021$ ).

The ratio of the two measurements ranged between $64.5 \pm 10.9 \%(\mathrm{Zr}-\mathrm{h})$ and $66.7 \pm 22.1 \%$ $(\mathrm{Zr}-\mathrm{m})$, without significant differences (param. MM intergroup: $p=0.985$ ).

\section{More complex mixed modelling}

Because of the small sample size, a complex modelling for the primary outcome (inflammatory cells at the level of the junctional epithelium) with more than three variables was not reasonable. Hence, only one additional factor was added to the two considered factors cleaning and implant (i.e. the four study groups). Nonparametric MM of the primary outcome did not reveal significant effects of jaw, gender, smoking, BoP at 3W, PD at 3W and presence of a GBR.

Based on the differences ( $\mathrm{Ti}-\mathrm{Zr}$ ) of the primary outcome and only one explanatory variable, the influence of cleaning (param. $p=0.326$ ), mean PI at $3 W$ (param. $p=0.608$ ), mean PD at $3 W$ (parametric $p=0.046$ ), mean BoP at $3 W$ (parametric $p=0.449$ ), mean length of the junctional epithelium (parametric $p=0.769$ ), ratio of the length of the junctional epithelium and overall tissue thickness were not significant (param. $p=0.848$ ). More parametric linear models with cleaning and an additional factor did not reveal any significant effects of these differences (Ti-Zr).

Modelling was repeated, using the difference of the lengths of the junctional epithelium at $\mathrm{BL}$ and $3 \mathrm{~W}$ as a dependent variable. None of the linear models, always including cleaning, revealed any significant influences $(p>0.05)$, except for the mean number of fibroblasts at the level of the junctional epithelium $(p=0.007)$.

This article is protected by copyright. All rights reserved 


\section{Discussion}

The present randomized controlled clinical trial revealed i) Overall very comparable outcomes for all four groups; ii) Clinically, a significant increase in plaque control record in the mucositis groups, with a significantly higher plaque control record for the titanium implant; iii) Clinically, a significant increase in BoP around titanium implants in the mucositis group, being also higher as compared to the zirconia implant; iv) Microbiologically, no differences and random appearance of marker pathogens; v) Histologically, no differences in terms of the number of inflammatory cells at the level of the junctional epithelium; vi) Histologically, an increase of tissue dimensions for the mucositis groups; vii) An association of higher probing depths with more inflammatory cells.

$\mathrm{Zr}-\mathrm{m}$ reported a lower PCR and Ti-m a lower BoP at baseline, while the other three groups were similar. From a clinical point of view, the baseline values are considered comparable for zirconia and titanium implants under healthy conditions. However, under experimental mucositis conditions, results were more favorable for zirconia implants. The plaque control record remained lower and bleeding on probing did not increase, while there was a significant increase for titanium implants. Expressed in a more accessible way, 2-3 out of 12 sites bled in average around zirconia implants, while 4 out of 12 sites bled around a titanium implant under mucositis conditions.

Based on the results of the plaque control record, the experimental mucositis experiment worked very well. However, compared to other studies, the expression of inflammatory parameters was clearly lower (Chan et al., 2019; Loe et al., 1965). One reason might be that the implants were unrestored and did therefore not allow for the same amount of plaque accumulation. The second reason might be that no splint was provided to the patient to cover this area during oral hygiene procedures. Even though the difference was not very distinct in the present study, lower plaque accumulation and bleeding scores when comparing zirconia and titanium on the abutment level have been reported earlier (Sanz-Martín, Sanz-Sánchez, Carrillo de Albornoz, Figuero, \& Sanz, 2018).

No trends were recognized for the microbiological outcomes. The variance for total bacterial loads was high, and the numbers did apparently not increase in the two experimental mucositis groups. Marker pathogens seemed to appear at random. No relation was detected when putting the result in context of the clinical situation or the histology of these patients. In contrast to the present results, a recently published study reported distinct differences based on only 16 patients (Clever et al., 2019). Samples were obtained for a tooth, a titanium and a zirconia dental implant within the same patient. More favorable results were

This article is protected by copyright. All rights reserved 
found for zirconia in terms of total bacterial load as well as presence of Tannerella forsythia and Prevotella intermedia.

Most of the histological results are also exhibiting a large variance. This feature is in line with the experience of the descriptive histologic assessment, where factors between patients seemed to vary far more than between the four groups. But the number of inflammatory cells at the level of the junctional epithelium was clearly higher compared to the other evaluated regions, as expected from early preclinical studies (Berglundh et al., 1991; Lindhe et al., 1992). Also clinical studies found the infiltrates mainly behind the junctional epithelium (Thoma et al., 2018). Most inflammatory cells were found in group Zr-h. This finding coincided with the descriptive histology, reporting more than half of the most distinct infiltrates in this group. While the other three groups reported similar outcomes, group Zr-h reported slightly inferior results not only for the inflammatory cells, but also for several histological scorings. The missing correlation between the clinical and histological results might be explained by the type of the infiltrate. The present lymphoplasmacytic infiltrates indicate an immunologic or chronic reaction rather than a reaction to bacterial inflammation, which would be related to a presence of neutrophil granulocytes.

Some trends were recognized with regards to the histometric assessment, when comparing the healthy and mucositis groups. Beside the high variance, the reduced number of measurements limited the power for these outcomes. Only biopsies with a continuous, fully intact junctional epithelium on both sides were evaluated. Interestingly, the two mucositis groups had a longer junctional epithelium as well as a significantly increased overall soft tissue thickness. Therefore, the ratio of the two factors was not affected. It can be speculated that this is not an elongation of the junctional epithelium, but an overall increase of the dimension probably due to oedema in the mucositis groups. In contrast to the present results, other studies reported a longer junctional epithelium and therefore an increased biologic width in six minipigs (Linares et al., 2016). This was interpreted as a positive feature, although the overall tissue thickness was similar, with titanium implants having a longer sulcular epithelium. Earlier preclinical studies did not find differences of these dimensions around zirconia and titanium abutments (Welander et al., 2008).

Very few interactions were recognized to explain an association of clinical and histological data. In order to evaluate potential confounding factors, other attempts were made to analyze the data. For example by using the clinical data of the two sites facing the biopsy only, instead of using all six sites around the implant. Another attempt was made in order to investigate more pronounced mucositis reactions, by stratifying the data according to PCR at 3 W. A comparison between the better cleaners (50\%) versus the worse cleaners $(50 \%)$ and 
another attempt using the best $20 \%$ versus the worst $20 \%$ of cleaners was performed. However, very similar outcomes were obtained with the same negative tendencies for group $\mathrm{Zr}-\mathrm{h}$ in regards to histologic outcomes, and therefore, this attempt was discarded. Vice versa, this can be interpreted as a success of randomization.

Considering the large number of performed statistical models, the presented differences must be interpreted with caution. Although the study is based on a robust design, some limitations have to be kept in mind. The number of patients is a limiting factor, especially in respect to the histometric outcomes, as not all biopsies could be evaluated. Compared to block sections in animal studies, the predictability of tissue removal and measuring is inferior. The experimental mucositis experiment could have provoked a more distinct inflammatory reaction. It is recommended to use splints in order to achieve this goal. The proximity of the two sites can also be considered as a limitation, with sites potentially influencing each other. Ideally, the geometry of the implants should be absolutely similar. Although the soft tissue neck was similar, the titanium implant carried a healing abutment and therefore also had a microgap. For the zirconia implant, it was decided not to use the available PEEK cap in order to avoid a different material. Zirconia caps were considered, but this would have introduced a cement margin. Having no cap on the zirconia implant seemed to be the best solution, but led to frequent soft tissue growth over the implant shoulder, which might have affected the accessibility for probing. Furthermore, the evaluation of immunological factors has not been considered in the present study.

This article is protected by copyright. All rights reserved 


\section{Conclusions}

The present randomized controlled clinical trial revealed similar clinical outcomes for zirconia and titanium dental implants under healthy conditions. Lower plaque and bleeding scores were found around zirconia implants under experimental mucositis conditions. No significant differences between groups were found for the majority of the histological results, including the number of inflammatory cells and the length of the junctional epithelium.

This article is protected by copyright. All rights reserved 


\section{Figure Legend}

Figure 1a-c Implant placement; a) after flap elevation; b) after implant placement; c) at the end of surgery.

Figure 2a-d Biopsy removal after experimental mucositis phase; a) healing abutment removal ( $\mathrm{Ti}$ implant) and incision design; $b+c$ ) buccal suture in order to mark the orientation of the biopsy; d) healing cap/abutment and inverting mattress suture.

Figure 3a-c Histologies displaying; a) placement of regions of interest underneath the oral epithelium, sulcular epithelium, junctional epithelium and supracrestal connective tissue at the left side and measurement of the length of the junctional epithelium and soft tissue thickness at the right side; b) representative biopsy showing a long junctional epithelium at both sides and a clear inflammatory infiltrate at the right side (group $\mathrm{Zr}-\mathrm{h}$ ) from a patient with very good plaque control; c) representative biopsy with a both-sided short junctional epithelium and a very clear collagen fiber orientation in the center.

Figure 4a-c Boxplot illustration of clinical findings before (Baseline) and after ( 3 weeks) the experimental mucositis experiment and histologic findings at 3 weeks: a) Plaque control record (PCR); b)bleeding on probing (BoP); c) Histomorphometrically evaluated number of inflammatory cells at the level of the junctional epithelium; $\mathrm{Zr}-\mathrm{h}=$ zirconia implant, healthy; $\mathrm{Ti}-\mathrm{h}=$ titanium implant, healthy; Zr-m = zirconia implant, mucositis; Ti-m = titanium implant, mucositis; All medians which are not clearly visible are overlapping with the first (25\%, lower) quartile; Whiskers: $10-90$ percentile.

Table 1 Baseline characteristics of patients/implants. Zr-h = zirconia implant, healthy; Ti-h = titanium implant, healthy; $\mathrm{Zr}-\mathrm{m}=$ zirconia implant, mucositis; Ti-m = titanium implant, mucositis; $\mathrm{Q} 1=25 \%$ quartile; $\mathrm{Q} 3=75 \%$ quartile.

Table 2 Descriptive data of all clinical parameters. $\mathrm{N}=$ number; SD = standard deviation; Min = minimum; $\mathrm{Q} 125 \%$ quartile; $\mathrm{Q} 3=75 \%$ quartile; Max = maximum; $\mathrm{PCR}$ = plaque control record; $\mathrm{BOP}=$ bleeding on probing; $\mathrm{PD}=$ probing depth; $\mathrm{KT}=$ keratinized tissue; $\mathrm{Zr}$ $\mathrm{h}=$ Zirconia implant, healthy; Ti-h = Titanium implant, healthy; Zr-m = Zirconia implant, mucositis; Ti-m = Titanium implant, mucositis.

Table 3 Descriptive data of histomorphometric analysis. $\mathrm{N}=$ number; $\mathrm{SD}=$ standard deviation; Min = minimum; $\mathrm{Q} 125 \%$ quartile; $\mathrm{Q} 3=75 \%$ quartile; Max = maximum; JE length = length of junctional epithelium; BW length = Overall soft tissue thickness; OE = oral 
epithelium; $\mathrm{SE}=$ sulcular epithelium; $\mathrm{JE}=$ junctional epithelium; $\mathrm{CT}=$ supracrestal connective tissue; $\mathrm{Zr}-\mathrm{h}=$ Zirconia implant, healthy; Ti-h = Titanium implant, healthy; $\mathrm{Zr}-\mathrm{m}$ = Zirconia implant, mucositis; Ti-m = Titanium implant, mucositis.

Appendix 1 Microbiological parameters. $\mathrm{N}=$ number; SD = standard deviation; Min = minimum; Q1 25\% quartile; $\mathrm{Q} 3=75 \%$ quartile; Max = maximum; $\mathrm{TBL}=$ total bacterial load; Marker pathogen = presence of a marker pathogen; Zr-h = Zirconia implant, healthy; $\mathrm{Ti}-\mathrm{h}=$ Titanium implant, healthy; Zr-m = Zirconia implant, mucositis; Ti-m = Titanium implant, mucositis.

Appendix 2 Pairwise comparisons of $\mathrm{Ti}$ - $\mathrm{Zr}$ under healthy and under mucositis conditions with parametric and non-parametric 95\%-confidence intervals $(\mathrm{CI})$. $\mathrm{PCR}=$ plaque control record; BoP = bleeding on probing; $\mathrm{PD}=$ probing depth; JE inflammcells = inflammatory cells at the level of the junctional epithelium; JE length = length of the junctional epithelium; $\mathrm{Zr}-\mathrm{h}$ = Zirconia implant, healthy; Ti-h = Titanium implant, healthy; Zr-m = Zirconia implant, mucositis; Ti-m = Titanium implant, mucositis. 


\section{Conflict of interest and funding}

The study is funded by a grant of the International Team for Implantology (1018-2014). Material support was granted by Straumann Holding AG. Dres Thoma, Hämmerle and Jung report further grants from the ITI outside of the submitted work. Dres Thoma, Hämmerle, Jung and Bienz report further grants and lecture support from Straumann Holding AG outside of the submitted work.

This article is protected by copyright. All rights reserved 


\section{Acknowledgements}

The authors express their gratitude to Ms Sonja Hitz for histologic processing and for the histomorphometric analysis. Benjamin Lanz is acknowledged for supporting and calibrating the digital morphometric evaluation. The help of Ms Gisela Müller for the data management is highly appreciated.

This article is protected by copyright. All rights reserved 


\section{Data availability statement}

The data that support the findings of this study are available from the corresponding author upon reasonable request.

This article is protected by copyright. All rights reserved 


\section{References}

Abrahamsson, I., Berglundh, T., Glantz, P. O., \& Lindhe, J. (1998). The mucosal attachment at different abutments. An experimental study in dogs. Journal of Clinical Periodontology, 25(9), 721-727. doi:10.1111/j.1600-051x.1998.tb02513.x

Albrektsson, T., Canullo, L., Cochran, D., \& De Bruyn, H. (2016). "Peri-Implantitis": A Complication of a Foreign Body or a Man-Made "Disease". Facts and Fiction. Clinical Implant Dentistry and Related Research, 18(4), 840-849. doi:10.1111/cid.12427

Balmer, M., Spies, B. C., Kohal, R. J., Hämmerle, C. H., Vach, K., \& Jung, R. E. (2020). Zirconia implants restored with single crowns or fixed dental prostheses: 5-year results of a prospective cohort investigation. Clinical Oral Implants Research. doi: $10.1111 / \mathrm{clr} .13581$

Balmer, M., Spies, B. C., Vach, K., Kohal, R. J., Hämmerle, C. H. F., \& Jung, R. E. (2018). Three-year analysis of zirconia implants used for single-tooth replacement and threeunit fixed dental prostheses: A prospective multicenter study. Clinical Oral Implants Research, 29(3), 290-299. doi:10.1111/clr.13115

Barão, V. A., Mathew, M. T., Assunção, W. G., Yuan, J. C., Wimmer, M. A., \& Sukotjo, C. (2012). Stability of $\mathrm{cp}-\mathrm{Ti}$ and Ti-6Al-4V alloy for dental implants as a function of saliva pH - an electrochemical study. Clinical Oral Implants Research, 23(9), 1055-1062. doi:10.1111/j.1600-0501.2011.02265.x

Berglundh, T., Lindhe, J., Ericsson, I., Marinello, C. P., Liljenberg, B., \& Thomsen, P. (1991). The soft tissue barrier at implants and teeth. Clinical Oral Implants Research, 2(2), 81-90. doi:10.1034/j.1600-0501.1991.020206.x

Branemark, P. I., Hansson, B. O., Adell, R., Breine, U., Lindstrom, J., Hallen, O., \& Ohman, A. (1977). Osseointegrated implants in the treatment of the edentulous jaw. Experience from a 10-year period. Scandinavian Journal of Plastic and Reconstructive Surgery. Supplementum, 16, 1-132. 
Brunner, E. Domhof, S. and Langer, F. Nonparametric analysis of Longitudinal Data in Factorial Experiments. Wiley (2001).

Chan, D., Pelekos, G., Ho, D., Cortellini, P., \& Tonetti, M. S. (2019). The depth of the implant mucosal tunnel modifies the development and resolution of experimental peri-implant mucositis: A case-control study. Journal of Clinical Periodontology, 46(2), 248-255. doi:10.1111/jcpe.13066

Clever, K., Schlegel, K. A., Kniha, H., Conrads, G., Rink, L., Modabber, A., . . Kniha, K. (2019). Experimental peri-implant mucositis around titanium and zirconia implants in comparison to a natural tooth: part 2-clinical and microbiological parameters. International Journal of Oral and Maxillofacial Surgery, 48(4), 560-565. doi:10.1016/j.ijom.2018.10.017

De Bruyn, H., Christiaens, V., Doornewaard, R., Jacobsson, M., Cosyn, J., Jacquet, W., \& Vervaeke, S. (2017). Implant surface roughness and patient factors on long-term peri-implant bone loss. Periodontology 2000, 73(1), 218-227. doi:10.1111/prd.12177

Depprich, R., Zipprich, H., Ommerborn, M., Mahn, E., Lammers, L., Handschel, J., . . Meyer, U. (2008). Osseointegration of zirconia implants: an SEM observation of the boneimplant interface. Head Face Med, 4, 25. doi:10.1186/1746-160X-4-25

Guglielmotti, M. B., Domingo, M. G., Steimetz, T., Ramos, E., Paparella, M. L., \& Olmedo, D. G. (2015). Migration of titanium dioxide microparticles and nanoparticles through the body and deposition in the gingiva: an experimental study in rats. European Journal of Oral Sciences, 123(4), 242-248. doi:10.1111/eos.12190

Jung, R. E., Zembic, A., Pjetursson, B. E., Zwahlen, M., \& Thoma, D. S. (2012). Systematic review of the survival rate and the incidence of biological, technical, and aesthetic complications of single crowns on implants reported in longitudinal studies with a mean follow-up of 5 years. Clinical Oral Implants Research, 23 Suppl 6, 2-21. doi:10.1111/j.1600-0501.2012.02547.x 
Kohal, R. J., Weng, D., Bachle, M., \& Strub, J. R. (2004). Loaded custom-made zirconia and titanium implants show similar osseointegration: an animal experiment. Journal of Periodontology, 75(9), 1262-1268. doi:10.1902/jop.2004.75.9.1262

Linares, A., Grize, L., Munoz, F., Pippenger, B. E., Dard, M., Domken, O., \& Blanco-Carrion, J. (2016). Histological assessment of hard and soft tissues surrounding a novel ceramic implant: a pilot study in the minipig. Journal of Clinical Periodontology, 43(6), 538546. doi:10.1111/jcpe. 12543

Lindhe, J., Berglundh, T., Ericsson, I., Liljenberg, B., \& Marinello, C. (1992). Experimental breakdown of peri-implant and periodontal tissues. A study in the beagle dog. Clinical Oral Implants Research, 3(1), 9-16. doi:10.1034/j.1600-0501.1992.030102.x

Loe, H., Theilade, E., \& Jensen, S. B. (1965). Experimental Gingivitis in Man. Journal of Periodontology, 36, 177-187. doi:10.1902/jop.1965.36.3.177

Mombelli, A., Hashim, D., \& Cionca, N. (2018). What is the impact of titanium particles and biocorrosion on implant survival and complications? A critical review. Clinical Oral Implants Research, 29 Suppl 18, 37-53. doi:10.1111/clr.13305

Oliva, J., Oliva, X., \& Oliva, J. D. (2007). One-year follow-up of first consecutive 100 zirconia dental implants in humans: a comparison of 2 different rough surfaces. International Journal of Oral and Maxillofacial Implants, 22(3), 430-435.

Pettersson, M., Kelk, P., Belibasakis, G. N., Bylund, D., Molin Thoren, M., \& Johansson, A. (2017). Titanium ions form particles that activate and execute interleukin-1beta release from lipopolysaccharide-primed macrophages. Journal of Periodontal Research, 52(1), 21-32. doi:10.1111/jre.12364

Pjetursson, B. E., Thoma, D., Jung, R., Zwahlen, M., \& Zembic, A. (2012). A systematic review of the survival and complication rates of implant-supported fixed dental prostheses (FDPs) after a mean observation period of at least 5 years. Clinical Oral Implants Research, 23 Suppl 6, 22-38. doi:10.1111/j.1600-0501.2012.02546.x 
Roehling, S., Astasov-Frauenhoffer, M., Hauser-Gerspach, I., Braissant, O., Woelfler, H., Waltimo, T., ... Gahlert, M. (2017). In Vitro Biofilm Formation on Titanium and Zirconia Implant Surfaces. Journal of Periodontology, 88(3), 298-307. doi:10.1902/jop.2016.160245

Roehling, S., Gahlert, M., Janner, S., Meng, B., Woelfler, H., \& Cochran, D. L. (2019). Ligature-Induced Peri-implant Bone Loss Around Loaded Zirconia and Titanium Implants. International Journal of Oral and Maxillofacial Implants, 34(2), 357-365. doi:10.11607/jomi.7015

Roehling, S., Schlegel, K. A., Woelfler, H., \& Gahlert, M. (2018). Performance and outcome of zirconia dental implants in clinical studies: A meta-analysis. Clinical Oral Implants Research, 29 Suppl 16, 135-153. doi:10.1111/clr.13352

Salvi, G. E., Aglietta, M., Eick, S., Sculean, A., Lang, N. P., \& Ramseier, C. A. (2012). Reversibility of experimental peri-implant mucositis compared with experimental gingivitis in humans. Clin Oral Implants Res, 23(2), 182-190. doi:10.1111/j.16000501.2011.02220.x

Sanz-Martín, I., Sanz-Sánchez, I., Carrillo de Albornoz, A., Figuero, E., \& Sanz, M. (2018). Effects of modified abutment characteristics on peri-implant soft tissue health: A systematic review and meta-analysis. Clinical Oral Implants Research, 29(1), 118129. doi:10.1111/clr.13097

Scarano, A., Piattelli, M., Caputi, S., Favero, G. A., \& Piattelli, A. (2004). Bacterial adhesion on commercially pure titanium and zirconium oxide disks: an in vivo human study. Journal of Periodontology, 75(2), 292-296. doi:10.1902/jop.2004.75.2.292

Schliephake, H., Reiss, G., Urban, R., Neukam, F. W., \& Guckel, S. (1993). Metal release from titanium fixtures during placement in the mandible: an experimental study. International Journal of Oral and Maxillofacial Implants, 8(5), 502-511.

This article is protected by copyright. All rights reserved 
Schroeder, A., Pohler, O., \& Sutter, F. (1976). [Tissue reaction to an implant of a titanium hollow cylinder with a titanium surface spray layer]. SSO: Schweizerische Monatsschrift fur Zahnheilkunde, 86(7), 713-727.

Thoma, D. S., Wolleb, K., Bienz, S. P., Wiedemeier, D., Hämmerle, C. H. F., \& Sailer, I. (2018). Early histological, microbiological, radiological, and clinical response to cemented and screw-retained all-ceramic single crowns. Clinical Oral Implants Research, 29(10), 996-1006. doi:10.1111/clr.13366

Welander, M., Abrahamsson, I., \& Berglundh, T. (2008). The mucosal barrier at implant abutments of different materials. Clinical Oral Implants Research, 19(7), 635-641. doi:10.1111/j.1600-0501.2008.01543.x

This article is protected by copyright. All rights reserved 


\begin{tabular}{|c|c|c|c|c|c|c|}
\hline \multicolumn{2}{|l|}{ Group } & Zr-h & Ti-h & Zr-m & Ti-m & Total \\
\hline \multirow[t]{2}{*}{ Number } & Patients & \multicolumn{2}{|c|}{20} & \multicolumn{2}{|c|}{20} & 40 \\
\hline & Implants & 20 & 20 & 20 & 20 & 80 \\
\hline \multirow[t]{2}{*}{ Gender } & Male & \multicolumn{2}{|c|}{$8(40 \%)$} & \multicolumn{2}{|c|}{$14(70 \%)$} & $22(55.0 \%)$ \\
\hline & Female & \multicolumn{2}{|c|}{$12(60 \%)$} & \multicolumn{2}{|c|}{$6(30 \%)$} & $18(45.0 \%)$ \\
\hline \multirow[t]{2}{*}{ Age } & Median & \multicolumn{2}{|c|}{52.5} & \multicolumn{2}{|c|}{62.1} & 55.4 \\
\hline & Quartile (first;third) & \multicolumn{2}{|c|}{$36.8 ; 61.3$} & \multicolumn{2}{|c|}{$51.5 ; 69.5$} & $45.6 ; 65.3$ \\
\hline \multirow[t]{2}{*}{ Smoking } & Up to $20 \mathrm{Cig} /$ day & \multicolumn{2}{|c|}{$4(20 \%)$} & \multicolumn{2}{|c|}{$6(30 \%)$} & $10(25 \%)$ \\
\hline & Former Smoker & \multicolumn{2}{|c|}{$4(20 \%)$} & \multicolumn{2}{|c|}{$7(35 \%)$} & $11(27.5 \%)$ \\
\hline \multirow[t]{2}{*}{ Jaw } & Maxilla & \multicolumn{2}{|c|}{$5(25 \%)$} & \multicolumn{2}{|c|}{$9(45 \%)$} & $14(35 \%)$ \\
\hline & Mandible & \multicolumn{2}{|c|}{$15(75 \%)$} & \multicolumn{2}{|c|}{$11(55 \%)$} & $26(65 \%)$ \\
\hline \multirow[t]{2}{*}{ Site } & Premolar & $10(50 \%)$ & $7(35 \%)$ & $13(65 \%)$ & $9(45 \%)$ & 39 (48.75\%) \\
\hline & Molar & $10(50 \%)$ & $13(65 \%)$ & $7(35 \%)$ & $11(55 \%)$ & 41 (51.25\%) \\
\hline \multirow[t]{3}{*}{ Augmentations } & Dehiscence & $3(15 \%)$ & $3(15 \%)$ & $4(20 \%)$ & $4(20 \%)$ & $12(15 \%)$ \\
\hline & Intrabony defect & $1(5 \%)$ & $1(5 \%)$ & $0(0 \%)$ & $0(0 \%)$ & $2(2.5 \%)$ \\
\hline & Crestal sinus lift & $0(0 \%)$ & $0(0 \%)$ & $1(5 \%)$ & $1(5 \%)$ & $2(2.5 \%)$ \\
\hline
\end{tabular}




\begin{tabular}{|c|c|c|c|c|c|c|c|c|c|c|}
\hline & Variable & Group & $\mathrm{n}$ & Mean & SD & Min & Q1 & Median & Q3 & Max \\
\hline \multirow{16}{*}{ 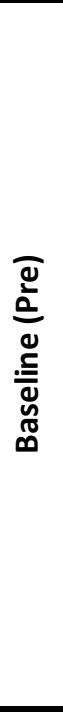 } & \multirow{4}{*}{ PCR (\%) } & $\mathrm{Zr}-\mathrm{h}$ & 20 & 10.83 & 21.13 & 0.00 & 0.00 & 0.00 & 16.67 & 66.67 \\
\hline & & Ti-h & 20 & 14.17 & 23.74 & 0.00 & 0.00 & 0.00 & 16.67 & 100 \\
\hline & & $\mathrm{Zr}-\mathrm{m}$ & 20 & 4.17 & 7.40 & 0.00 & 0.00 & 0.00 & 8.33 & 16.67 \\
\hline & & Ti-m & 20 & 14.17 & 27.19 & 0.00 & 0.00 & 0.00 & 16.67 & 100 \\
\hline & \multirow{4}{*}{ BoP (\%) } & Zr-h & 20 & 22.50 & 20.43 & 0.00 & 12.50 & 16.67 & 33.33 & 66.67 \\
\hline & & Ti-h & 20 & 15.83 & 18.32 & 0.00 & 0.00 & 16.67 & 25.00 & 50.00 \\
\hline & & Zr-m & 20 & 22.50 & 23.74 & 0.00 & 0.00 & 16.67 & 41.67 & 83.33 \\
\hline & & Ti-m & 20 & 20.83 & 18.63 & 0.00 & 0.00 & 16.67 & 33.33 & 66.67 \\
\hline & \multirow{4}{*}{$\mathrm{PD}(\mathrm{mm})$} & $\mathrm{Zr}-\mathrm{h}$ & 20 & 2.58 & 0.47 & 1.50 & 2.25 & 2.58 & 3.00 & 3.17 \\
\hline & & Ti-h & 20 & 2.71 & 0.55 & 1.67 & 2.33 & 2.67 & 3.08 & 3.67 \\
\hline & & $\mathrm{Zr}-\mathrm{m}$ & 20 & 2.67 & 0.46 & 1.67 & 2.33 & 2.83 & 3.00 & 3.17 \\
\hline & & Ti-m & 20 & 2.74 & 0.67 & 1.00 & 2.50 & 2.75 & 3.00 & 4.00 \\
\hline & \multirow{4}{*}{$\mathrm{KT}(\mathrm{mm})$} & $\mathrm{Zr}-\mathrm{h}$ & 20 & 3.30 & 1.45 & 1.00 & 2.00 & 3.00 & 4.00 & 7.00 \\
\hline & & Ti-h & 20 & 3.40 & 1.57 & 2.00 & 2.00 & 3.00 & 4.00 & 8.00 \\
\hline & & $\mathrm{Zr}-\mathrm{m}$ & 20 & 3.10 & 1.25 & 1.00 & 2.00 & 3.00 & 4.00 & 6.00 \\
\hline & & Ti-m & 20 & 3.10 & 1.02 & 1.00 & 3.00 & 3.00 & 4.00 & 5.00 \\
\hline \multirow{16}{*}{ 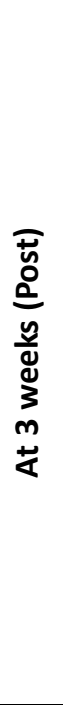 } & \multirow{4}{*}{ PCR (\%) } & $\mathrm{Zr}-\mathrm{h}$ & 20 & 12.50 & 16.99 & 0.00 & 0.00 & 0.00 & 33.33 & 50.00 \\
\hline & & Ti-h & 20 & 14.17 & 18.95 & 0.00 & 0.00 & 8.33 & 16.67 & 66.67 \\
\hline & & Zr-m & 20 & 68.33 & 31.94 & 0.00 & 50.00 & 66.67 & 100 & 100 \\
\hline & & Ti-m & 20 & 75.00 & 29.37 & 0.00 & 58.33 & 83.33 & 100 & 100 \\
\hline & \multirow{4}{*}{ BoP (\%) } & $\mathrm{Zr}-\mathrm{h}$ & 20 & 11.67 & 18.81 & 0.00 & 0.00 & 0.00 & 16.67 & 66.67 \\
\hline & & Ti-h & 20 & 11.67 & 16.31 & 0.00 & 0.00 & 0.00 & 16.67 & 50.00 \\
\hline & & $\mathrm{Zr}-\mathrm{m}$ & 20 & 21.67 & 23.63 & 0.00 & 0.00 & 16.67 & 33.33 & 83.33 \\
\hline & & Ti-m & 20 & 32.50 & 27.82 & 0.00 & 16.67 & 16.67 & 58.33 & 83.33 \\
\hline & \multirow{4}{*}{$\mathrm{PD}(\mathrm{mm})$} & $\mathrm{Zr}-\mathrm{h}$ & 20 & 2.56 & 0.35 & 2.00 & 2.25 & 2.67 & 2.83 & 3.00 \\
\hline & & Ti-h & 20 & 2.53 & 0.30 & 2.00 & 2.25 & 2.50 & 2.83 & 3.00 \\
\hline & & $\mathrm{Zr}-\mathrm{m}$ & 20 & 2.37 & 0.40 & 1.67 & 2.08 & 2.33 & 2.75 & 3.00 \\
\hline & & Ti-m & 20 & 2.63 & 0.38 & 2.00 & 2.33 & 2.67 & 3.00 & 3.33 \\
\hline & \multirow{4}{*}{$\mathrm{KT}(\mathrm{mm})$} & Zr-h & 20 & 3.45 & 1.39 & 1.00 & 2.00 & 3.00 & 5.00 & 6.00 \\
\hline & & Ti-h & 20 & 3.05 & 1.64 & 1.00 & 2.00 & 3.00 & 3.50 & 8.00 \\
\hline & & $\mathrm{Zr}-\mathrm{m}$ & 19 & 3.47 & 1.43 & 2.00 & 2.00 & 3.00 & 5.00 & 6.00 \\
\hline & & Ti-m & 19 & 3.05 & 1.51 & 0.00 & 2.00 & 3.00 & 4.00 & 6.00 \\
\hline
\end{tabular}




\begin{tabular}{|c|c|c|c|c|c|c|c|c|c|c|}
\hline & Variable & Group & $n$ & Mean & SD & Min & Q1 & Median & Q3 & Max \\
\hline \multirow{12}{*}{ 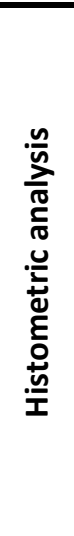 } & \multirow{4}{*}{$\begin{array}{l}\text { JE length } \\
(\mu \mathrm{m})\end{array}$} & $\overline{Z r-h}$ & 8 & 1213.46 & 243.32 & 875.27 & 1005.28 & 1243.81 & 1359.91 & 1614.39 \\
\hline & & Ti-h & 8 & 1344.59 & 430.08 & 536.26 & 1129.74 & 1354.76 & 1687.08 & 1877.28 \\
\hline & & $\mathrm{Zr}-\mathrm{m}$ & 14 & 1664.80 & 668.79 & 928.87 & 1238.46 & 1498.70 & 1919.56 & 3579.82 \\
\hline & & Ti-m & 14 & 1557.64 & 473.28 & 845.21 & 1226.79 & 1471.19 & 2042.53 & 2297.75 \\
\hline & \multirow{4}{*}{$\begin{array}{c}\text { BW } \\
\text { length } \\
(\mu \mathrm{m})\end{array}$} & Zr-h & 8 & 1924.87 & 476.27 & 1284.06 & 1518.45 & 1930.02 & 2335.29 & 2547.33 \\
\hline & & Ti-h & 8 & 2056.40 & 431.89 & 1646.92 & 1707.69 & 1931.42 & 2334.95 & 2856.19 \\
\hline & & $\mathrm{Zr}-\mathrm{m}$ & 14 & 2484.78 & 431.25 & 1942.08 & 2121.53 & 2433.61 & 2681.39 & 3382.23 \\
\hline & & Ti-m & 14 & 2387.24 & 510.37 & 1731.10 & 1908.36 & 2371.46 & 2763.18 & 3442.96 \\
\hline & \multirow{4}{*}{$\begin{array}{l}\mathrm{JE} / \mathrm{BW} \\
\text { ratio (\%) }\end{array}$} & $Z r-h$ & 8 & 64.45 & 10.92 & 51.68 & 57.26 & 58.75 & 76.38 & 79.15 \\
\hline & & Ti-h & 8 & 65.92 & 20.28 & 30.19 & 57.58 & 65.39 & 76.43 & 98.37 \\
\hline & & $\mathrm{Zr}-\mathrm{m}$ & 14 & 66.66 & 22.06 & 43.78 & 54.61 & 57.95 & 71.60 & 122.27 \\
\hline & & Ti-m & 14 & 65.36 & 19.70 & 35.24 & 49.45 & 67.96 & 79.19 & 101.21 \\
\hline \multirow{16}{*}{ 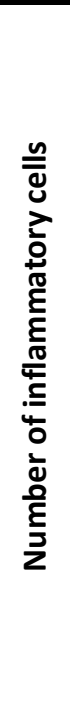 } & \multirow{4}{*}{ OE (\%) } & $Z r-h$ & 19 & 0.48 & 0.83 & 0.06 & 0.12 & 0.23 & 0.38 & 3.72 \\
\hline & & Ti-h & 19 & 0.83 & 2.01 & 0.07 & 0.14 & 0.29 & 0.38 & 8.87 \\
\hline & & $\mathrm{Zr}-\mathrm{m}$ & 19 & 0.31 & 0.24 & 0.08 & 0.14 & 0.20 & 0.41 & 0.83 \\
\hline & & Ti-m & 19 & 0.33 & 0.33 & 0.03 & 0.12 & 0.28 & 0.42 & 1.30 \\
\hline & \multirow{4}{*}{ SE (\%) } & Zr-h & 20 & 1.27 & 2.47 & 0.00 & 0.23 & 0.42 & 1.03 & 11.05 \\
\hline & & Ti-h & 20 & 1.08 & 1.76 & 0.05 & 0.19 & 0.35 & 0.98 & 6.53 \\
\hline & & $\mathrm{Zr}-\mathrm{m}$ & 19 & 0.98 & 1.17 & 0.00 & 0.20 & 0.56 & 1.07 & 4.18 \\
\hline & & Ti-m & 19 & 0.55 & 0.52 & 0.00 & 0.12 & 0.27 & 0.95 & 1.90 \\
\hline & \multirow{4}{*}{ JE (\%) } & Zr-h & 20 & 4.80 & 5.65 & 0.07 & 0.52 & 2.34 & 7.20 & 20.20 \\
\hline & & Ti-h & 20 & 3.11 & 5.70 & 0.07 & 0.49 & 1.34 & 3.00 & 25.98 \\
\hline & & $\mathrm{Zr}-\mathrm{m}$ & 19 & 1.95 & 3.18 & 0.21 & 0.34 & 0.65 & 2.70 & 14.03 \\
\hline & & Ti-m & 19 & 2.24 & 3.10 & 0.08 & 0.27 & 0.72 & 3.35 & 10.48 \\
\hline & \multirow{4}{*}{ CT (\%) } & Zr-h & 18 & 1.84 & 2.43 & 0.05 & 0.21 & 0.48 & 3.82 & 7.10 \\
\hline & & Ti-h & 19 & 0.95 & 1.13 & 0.04 & 0.15 & 0.43 & 1.32 & 3.63 \\
\hline & & $\mathrm{Zr}-\mathrm{m}$ & 19 & 1.17 & 1.29 & 0.05 & 0.27 & 0.52 & 1.66 & 3.97 \\
\hline & & Ti-m & 19 & 0.77 & 0.66 & 0.00 & 0.22 & 0.55 & 1.12 & 2.54 \\
\hline \multirow{16}{*}{ 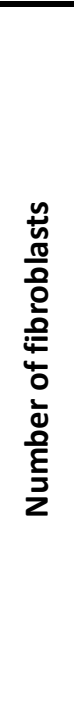 } & \multirow{4}{*}{$\mathrm{OE}(\%)$} & Zr-h & 19 & 5.57 & 3.07 & 2.23 & 2.70 & 4.18 & 7.88 & 11.72 \\
\hline & & Ti-h & 19 & 4.87 & 2.20 & 2.41 & 3.34 & 4.25 & 6.01 & 11.10 \\
\hline & & $\mathrm{Zr}-\mathrm{m}$ & 19 & 4.06 & 2.23 & 1.65 & 2.41 & 3.55 & 5.08 & 11.65 \\
\hline & & Ti-m & 19 & 4.49 & 1.46 & 2.11 & 3.46 & 4.35 & 5.27 & 8.54 \\
\hline & \multirow{4}{*}{ SE (\%) } & Zr-h & 20 & 5.44 & 2.72 & 1.80 & 3.30 & 4.83 & 7.32 & 10.77 \\
\hline & & Ti-h & 20 & 4.32 & 2.19 & 1.16 & 2.73 & 3.96 & 5.86 & 9.21 \\
\hline & & Zr-m & 19 & 5.36 & 2.12 & 1.76 & 3.38 & 5.33 & 6.53 & 9.44 \\
\hline & & Ti-m & 19 & 4.11 & 1.62 & 1.70 & 2.85 & 4.12 & 5.01 & 7.33 \\
\hline & \multirow{4}{*}{ JE (\%) } & Zr-h & 20 & 6.29 & 3.62 & 2.36 & 3.60 & 6.01 & 7.40 & 18.42 \\
\hline & & Ti-h & 20 & 3.88 & 1.26 & 2.27 & 2.93 & 3.48 & 4.88 & 7.24 \\
\hline & & Zr-m & 19 & 5.52 & 3.88 & 1.47 & 3.34 & 4.79 & 6.65 & 19.52 \\
\hline & & Ti-m & 19 & 4.56 & 2.71 & 2.00 & 2.77 & 3.96 & 4.94 & 13.46 \\
\hline & \multirow{4}{*}{ CT (\%) } & Zr-h & 18 & 5.29 & 3.67 & 1.27 & 2.80 & 4.51 & 6.63 & 14.80 \\
\hline & & Ti-h & 19 & 3.92 & 2.16 & 0.87 & 2.49 & 3.74 & 4.98 & 10.04 \\
\hline & & $\mathrm{Zr}-\mathrm{m}$ & 19 & 3.97 & 1.98 & 1.00 & 2.05 & 3.89 & 5.72 & 7.96 \\
\hline & & Ti-m & 19 & 3.65 & 1.36 & 1.67 & 2.63 & 3.46 & 4.62 & 6.54 \\
\hline
\end{tabular}



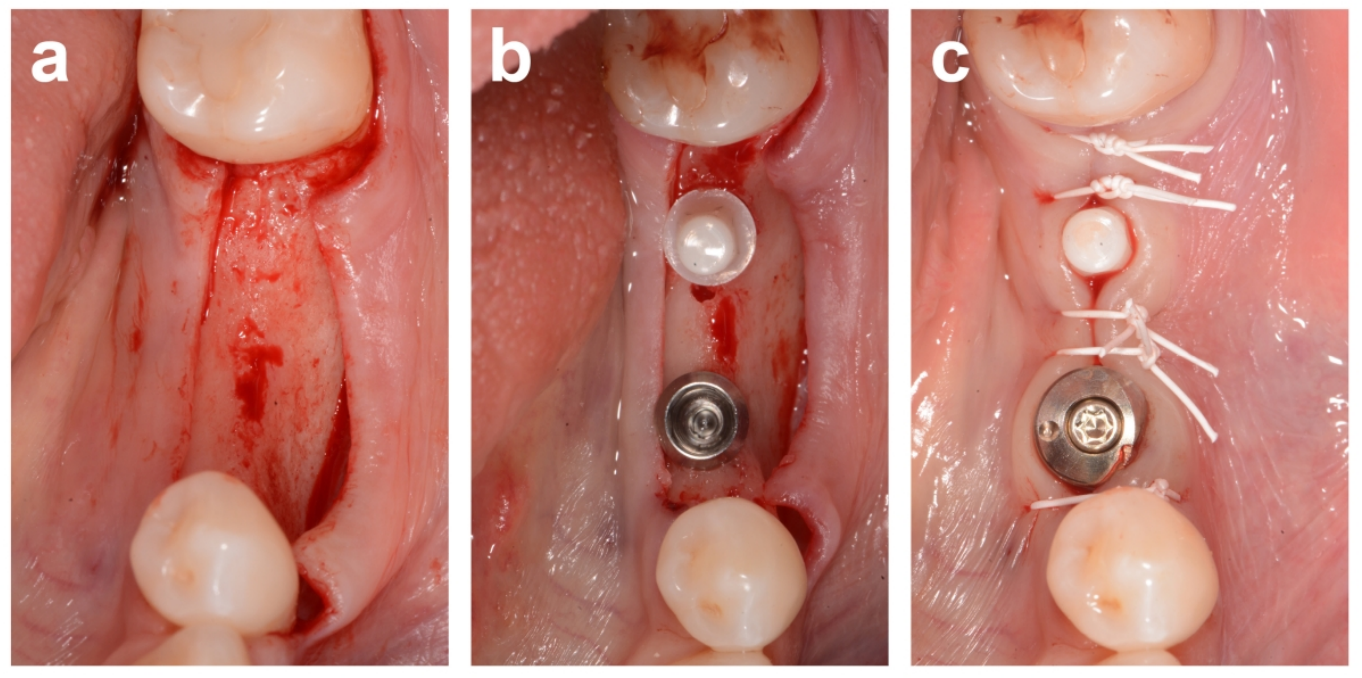

jcpe_13411_f1.jpg

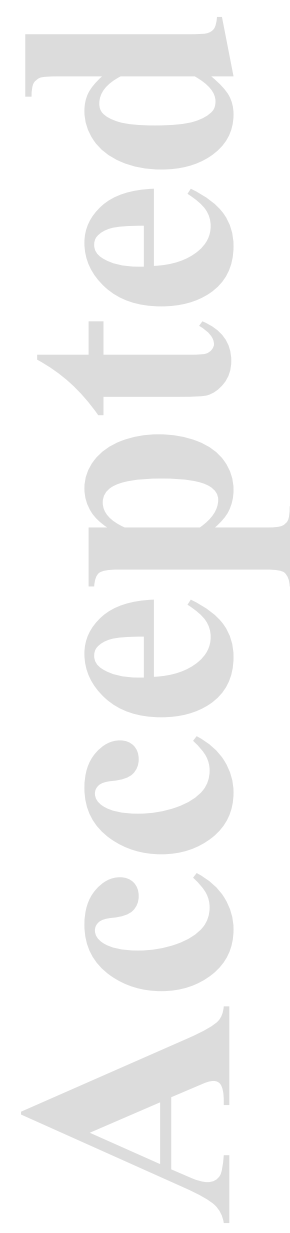

This article is protected by copyright. All rights reserved 

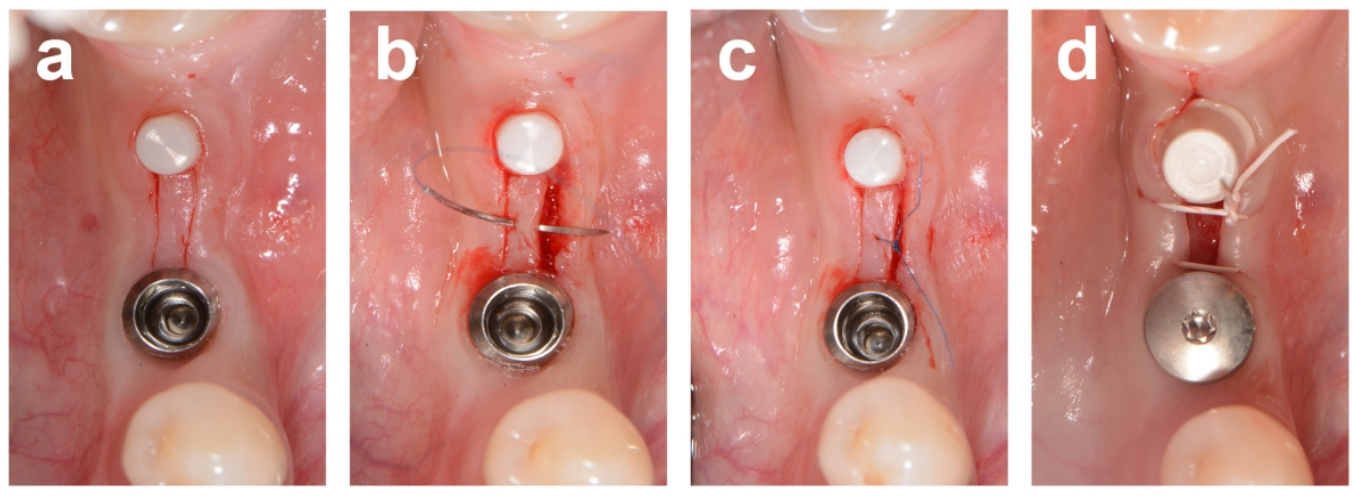

jcpe_13411_f2.jpg 

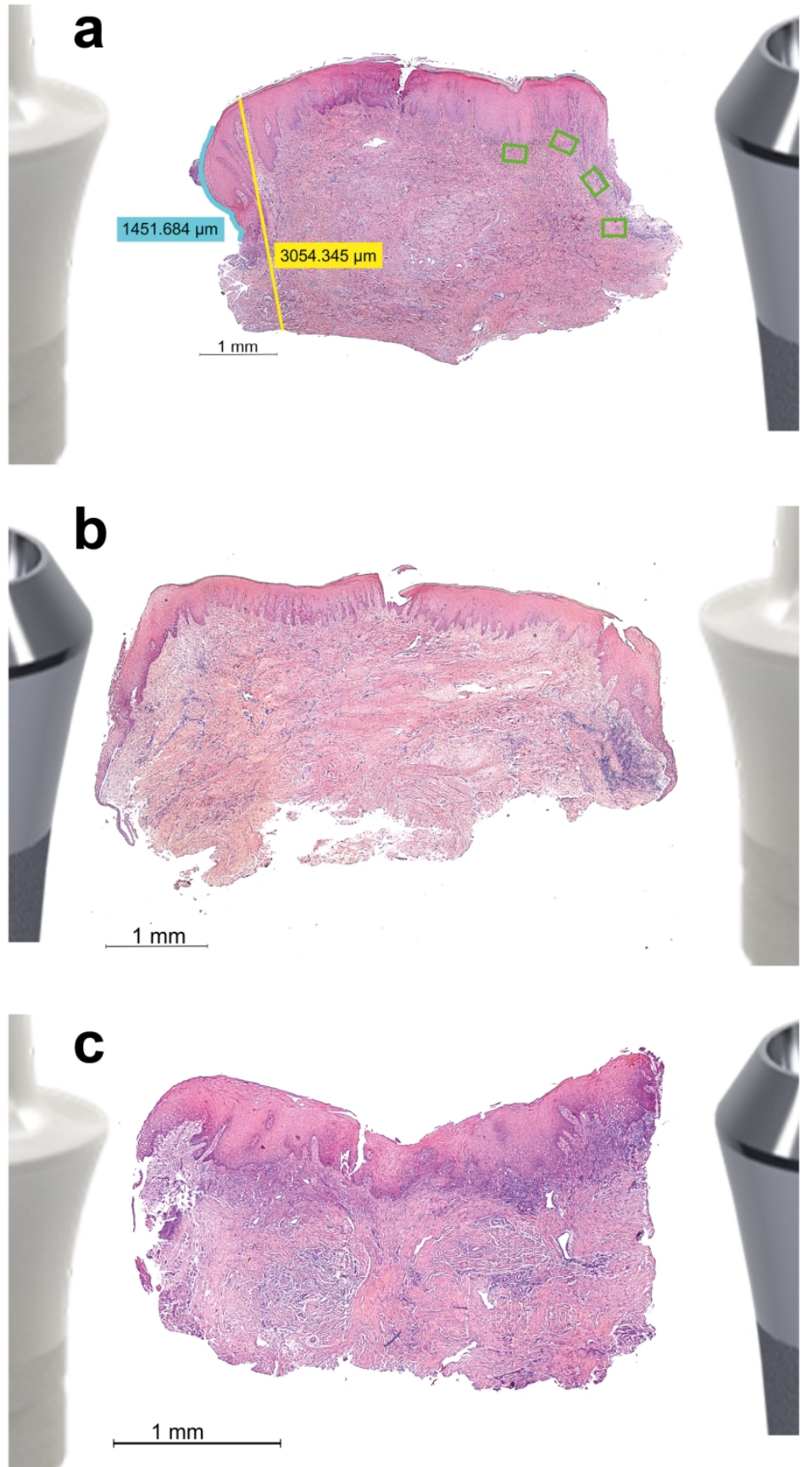

jcpe_13411_f3.jpg

This article is protected by copyright. All rights reserved 


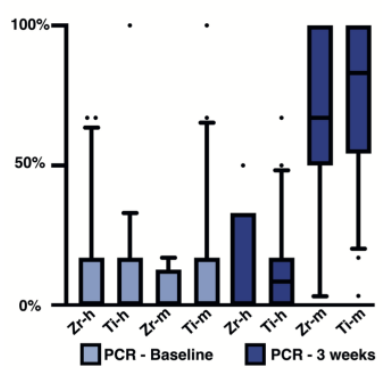

a
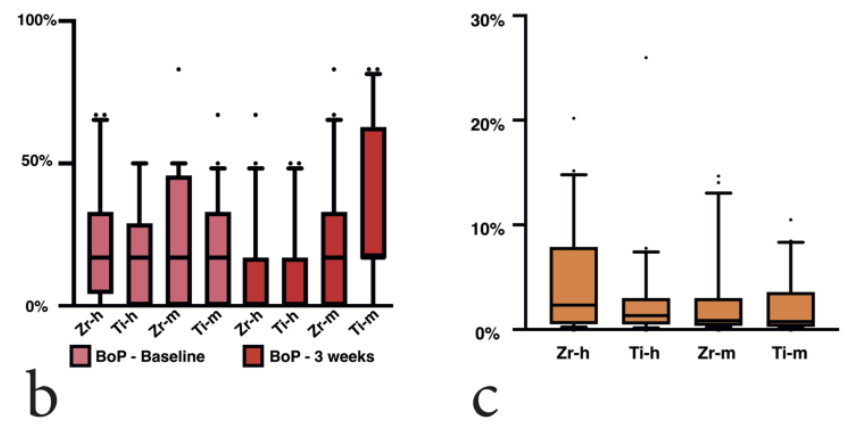

jcpe_13411_f4.tiff 


\begin{tabular}{|c|c|c|c|c|c|c|c|c|c|c|}
\hline & Variable & Group & $\mathbf{n}$ & Mean & SD & Min & Q1 & $\begin{array}{c}\text { Media } \\
\mathrm{n}\end{array}$ & Q3 & Max \\
\hline \multirow{8}{*}{ 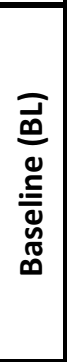 } & \multirow{4}{*}{ TBL (n, millions) } & $Z r-h$ & 20 & 27.97 & 26.24 & 0.29 & 3.71 & 21.42 & 45.73 & 78.35 \\
\hline & & Ti-h & 20 & 29.14 & 28.66 & 0.03 & 6.34 & 18.10 & 39.21 & 97.67 \\
\hline & & $\mathrm{Zr}-\mathrm{m}$ & 18 & 18.05 & 14.12 & 1.28 & 5.46 & 16.33 & 28.12 & 51.79 \\
\hline & & Ti-m & 18 & 15.30 & 14.95 & 0.93 & 2.14 & 13.24 & 18.45 & 53.40 \\
\hline & \multirow{4}{*}{$\begin{array}{c}\text { Marker pathogen } \\
(\%)\end{array}$} & $Z r-h$ & 20 & 5.00 & 22.00 & 0.00 & 0.00 & 0.00 & 0.00 & 100.00 \\
\hline & & Ti-h & 20 & 15.00 & 37.00 & 0.00 & 0.00 & 0.00 & 0.00 & 100.00 \\
\hline & & $\mathrm{Zr}-\mathrm{m}$ & 18 & 17.00 & 38.00 & 0.00 & 0.00 & 0.00 & 0.00 & 100.00 \\
\hline & & Ti-m & 18 & 0.00 & 0.00 & 0.00 & 0.00 & 0.00 & 0.00 & 0.00 \\
\hline \multirow{8}{*}{ 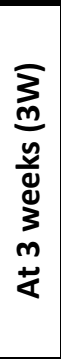 } & \multirow{4}{*}{ TBL (n, millions) } & $Z r-h$ & 20 & 16.20 & 15.89 & 0.14 & 3.61 & 10.27 & 26.96 & 49.96 \\
\hline & & Ti-h & 20 & 20.20 & 22.69 & 0.14 & 6.29 & 11.78 & 25.89 & 89.53 \\
\hline & & $\mathrm{Zr}-\mathrm{m}$ & 18 & 25.99 & 22.05 & 2.20 & 7.00 & 20.62 & 43.87 & 66.53 \\
\hline & & Ti-m & 18 & 21.69 & 22.61 & 1.14 & 4.31 & 16.34 & 31.85 & 88.12 \\
\hline & \multirow{4}{*}{$\begin{array}{c}\text { Marker pathogen } \\
(\%)\end{array}$} & $\mathrm{Zr}-\mathrm{h}$ & 20 & 5.00 & 22.00 & 0.00 & 0.00 & 0.00 & 0.00 & 100.00 \\
\hline & & Ti-h & 20 & 5.00 & 22.00 & 0.00 & 0.00 & 0.00 & 0.00 & 100.00 \\
\hline & & $\mathrm{Zr}-\mathrm{m}$ & 19 & 16.00 & 37.00 & 0.00 & 0.00 & 0.00 & 0.00 & 100.00 \\
\hline & & Ti-m & 19 & 11.00 & 32.00 & 0.00 & 0.00 & 0.00 & 0.00 & 100.00 \\
\hline
\end{tabular}




\begin{tabular}{|c|c|c|c|c|c|c|}
\hline & Variable & Group & $\begin{array}{c}\text { Median } \\
\text { (nonparametric) }\end{array}$ & $\begin{array}{c}\text { Estimate } \\
\text { (parametric) }\end{array}$ & Lower $\mathrm{Cl}(95 \%)$ & Upper Cl (95\%) \\
\hline \multirow{6}{*}{ 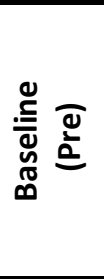 } & \multirow{2}{*}{ PCR (\%) } & Ti-h-Zr-h & 0.00 & & 0.00 & 0.17 \\
\hline & & Ti-m - Zr-m & 0.00 & & 0.00 & 0.17 \\
\hline & \multirow{2}{*}{ BoP (\%) } & Ti-h - Zr-h & 0.00 & & -0.17 & 0.00 \\
\hline & & Ti-m - Zr-m & 0.00 & & -0.17 & 0.17 \\
\hline & \multirow{2}{*}{$\mathrm{PD}(\mathrm{mm})$} & Ti-h - Zr-h & & 0.12 & 0.04 & 0.20 \\
\hline & & Ti-m - Zr-m & & 0.09 & 0.01 & 0.17 \\
\hline \multirow{6}{*}{ 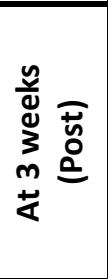 } & \multirow{2}{*}{ PCR (\%) } & Ti-h-Zr-h & 0.00 & & 0.00 & 0.17 \\
\hline & & Ti-m - Zr-m & 0.00 & & -0.17 & 0.17 \\
\hline & \multirow{2}{*}{ BoP (\%) } & Ti-h - Zr-h & 0.00 & & -0.17 & 0.00 \\
\hline & & Ti-m - Zr-m & 0.17 & & 0.00 & 0.17 \\
\hline & \multirow{2}{*}{$\mathrm{PD}(\mathrm{mm})$} & Ti-h - Zr-h & & -0.03 & -0.08 & 0.01 \\
\hline & & Ti-m - Zr-m & & 0.27 & 0.23 & 0.31 \\
\hline \multirow{4}{*}{ 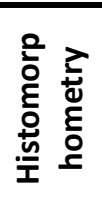 } & \multirow{2}{*}{$\begin{array}{c}\text { JE inflammcells } \\
(\%)\end{array}$} & Ti-h - Zr-h & -0.99 & & -4.22 & 0.68 \\
\hline & & Ti-m - Zr-m & 0.03 & & -1.05 & 1.07 \\
\hline & \multirow[t]{2}{*}{ JE length $(\mu \mathrm{m})$} & Ti-h - Zr-h & & 99.11 & -56.57 & 254.79 \\
\hline & & Ti-m - Zr-m & & -86.69 & -183.05 & 9.66 \\
\hline
\end{tabular}

